\title{
COMBINATION TREATMENT WITH ZIDOVUDINE, DIDANOSINE, AND NEVIRAPINE IN INFANTS WITH HUMAN IMMUNODEFICIENCY VIRUS TYPE 1 INFECTION
}

\author{
Katherine Luzuriaga, M.D., Yvonne Bryson, M.D., Paul Krogstad, M.D., James Robinson, M.D., \\ Barbara Stechenberg, M.D., Michael Lamson, Ph.D., Susannah Cort, M.D., and John L. Sullivan, M.D.
}

\begin{abstract}
Background In infants and children with maternally acquired human immunodeficiency virus type 1 (HIV-1) infection, treatment with a single antiretroviral agent has limited efficacy. We evaluated the safety and efficacy of a three-drug regimen in a small group of maternally infected infants.

Methods Zidovudine, didanosine, and nevirapine were administered in combination orally to eight infants 2 to 16 months of age. The efficacy of antiretroviral treatment was evaluated by serial measurements of plasma HIV-1 RNA, quantitative plasma cultures, and quantitative cultures of peripheral-blood mononuclear cells.

Results The three-drug regimen was well tolerated, without clinically important adverse events. Within four weeks, there were reductions in plasma levels of HIV-1 RNA of at least 96 percent $(1.5 \mathrm{log})$ in seven of the eight study patients. Over the 6-month study period, replication of HIV-1 was controlled in two infants who began therapy at $2 \frac{1}{2}$ months of age. Plasma RNA levels were reduced by 0.5 to $1.5 \mathrm{log}$ in five of the other six infants.

Conclusions Although further observations are needed, it appears that in infants with maternally acquired HIV-1 infection, combined treatment with zidovudine, didanosine, and nevirapine is well tolerated and has sustained efficacy against HIV-1. (N Engl J Med 1997;336:1343-9.)

(C)1997, Massachusetts Medical Society.
\end{abstract}

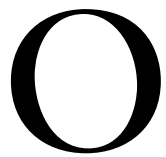
VER the past decade, the numbers of infants infected by the transmission of human immunodeficiency virus type l (HIV-l) from their mothers have increased greatly. In general, the depletion of CD4 cells and the progression of HIV-l-related disease are more rapid in infants and children than in adults infected with HIV-1. ${ }^{2}$ Effective interventional therapies for maternally infected children are needed.

For HIV-1-infected children, therapy has primarily consisted of a single inhibitor of reverse transcriptase, and its efficacy has been moderate and limited in duration. Recently, studies in adults ${ }^{3-6}$ have documented continuous, high-level replication of HIV-l even early in infection. These data have helped explain the limitations of prior therapeutic approaches and suggest that the best chance of preventing disease after HIV-I infection lies in controlling replication of the virus as early in the course of infection as possible.
Moderate reductions in the load of HIV-l in blood have been documented in infants who received nevirapine alone or in combination with zidovudine. ${ }^{7}$ Therefore, we sought to study the antiretroviral efficacy of a three-drug regimen consisting of zidovudine, didanosine, and nevirapine administered orally to maternally infected infants and children. Efforts were made to begin the combined treatment in the first few months of life.

\section{METHODS}

\section{Study Design}

This open-label, phase 1-2 study was conducted at two pediatric AIDS Clinical Trials Group (ACTG) sites (the Western New England Pediatric ACTG Consortium and the University of California, Los Angeles). HIV-1-infected infants 2 through 24 months of age were eligible for the study, but enrollment focused on infants under the age of 4 months. The details of the criteria for inclusion and exclusion, concomitant medications, and the schedule of evaluations have previously been described. ${ }^{7}$ Before enrollment, each participant had a complete history taking and physical examination, an evaluation of medications, and an electrocardiogram; a complete blood count; measurements of electrolytes, blood urea nitrogen, and creatinine; and tests of liver and thyroid function.

At each study visit, potential toxic effects of medications or HIV-1-related symptoms were assessed and a complete physical examination was performed. Height and weight were measured at entry into the study and monthly thereafter. The laboratory assessment of potential toxic effects of medications was made at enrollment, on days 14 and 28 , and monthly thereafter. Studies of lymphocyte surface markers were performed at enrollment and on days $28,56,84$, and 168 . Blood to measure the trough plasma concentration of nevirapine was obtained just before the nevirapine dose given at entry and on days $14,28,42,56,70,84$, and 168. Blood was collected to obtain viral isolates and measure plasma HIV-1 RNA at enrollment and on days 14, 28, 42, 56, $70,84,112,140$, and 168 . Medications were dispensed monthly, and the doses were adjusted for the infant's growth as necessary.

These studies were approved by the human-subjects committees at the participating sites; written informed consent was obtained from the patients' legal guardians. The guidelines of the U.S. Department of Health and Human Services governing experimentation in humans were followed.

From the Department of Pediatrics, University of Massachusetts Medical School, Worcester (K.L., J.L.S.); the Department of Pediatrics, University of California at Los Angeles, Los Angeles (Y.B., P.K.); the Department of Pediatrics, University of Connecticut Medical School, Farmington (J.R.); the Department of Pediatrics, Baystate Medical Center, Springfield, Mass. (B.S.); and Boehringer-Ingelheim Pharmaceuticals, Ridgefield, Conn. (M.L., S.C.). Address reprint requests to Dr. Luzuriaga at Pediatrics and Molecular Medicine, University of Massachusetts Medical School, Rm. 318, Biotech 2, 373 Plantation St., Worcester, MA 01605. 


\section{Study Medications}

The following doses of the study drugs were used: $120 \mathrm{mg}$ of nevirapine (Viramune, Boehringer-Ingelheim) per square meter of body-surface area, given once daily for 28 days, after which time $200 \mathrm{mg}$ per square meter was given every 12 hours; $180 \mathrm{mg}$ of zidovudine (Retrovir, Glaxo Wellcome) per square meter, given every 8 hours; and $120 \mathrm{mg}$ of didanosine (Videx, Bristol-Myers Squibb) per square meter, given every 12 hours. All the medications were supplied as suspensions or syrup (nevirapine, 5 and $10 \mathrm{mg}$ per milliliter; zidovudine, $10 \mathrm{mg}$ per milliliter; and didanosine, $10 \mathrm{mg}$ per milliliter).

\section{Measurement of Plasma Nevirapine}

Plasma nevirapine concentrations were measured by high-performance liquid chromatography with a validated procedure, as previously described.?

\section{Determination of Lymphocyte Subgroups}

The relative percentages of $\mathrm{CD} 3+\mathrm{CD} 4+, \mathrm{CD} 3+\mathrm{CD} 8+$, $\mathrm{CD} 8+\mathrm{DR}+, \mathrm{CD} 8+\mathrm{CD} 38+$, and CD8+CD57+ lymphocytes in peripheral blood were determined by direct immunofluorescence with fluorescein isothiocyanate or phycoerythrin-conjugated mouse monoclonal antibodies (Becton Dickinson). Samples were analyzed by flow cytometry (FACScan, Becton Dickinson).

\section{Quantitative Cultures of Plasma and Peripheral-Blood Mononuclear Cells}

Quantitative cultures of plasma and peripheral-blood mononuclear cells (PBMCs) were performed by limiting-dilution methods with standard protocols. ${ }^{8}$

\section{Detection and Quantitation of HIV-1 Genomes in PBMCs}

A commercially available kit (Roche Diagnostic Systems) was used to detect and quantify the HIV-l genome in the PBMCs of the study patients by the polymerase chain reaction (PCR). ${ }^{9}$

\section{Quantitation of Plasma HIV-1 RNA by PCR}

HIV-1 RNA was quantified in $200 \mu$ l of EDTA-anticoagulated plasma (stored at $-70^{\circ} \mathrm{C}$ within six hours after phlebotomy) by PCR after reverse transcription (Amplicor, Roche). The lower limit of detection of the assay is 400 copies of HIV-l RNA per milliliter of plasma. ${ }^{10}$ All the assays were performed in a laboratory that participates in an ongoing certification program for HIV RNA quantitation sponsored by the National Institutes of Health. ${ }^{10}$ The baseline plasma level of HIV-1 RNA was defined as the arithmetic mean of two measurements obtained within one month of the start of therapy. Sequential plasma samples from individual patients were assayed in batches to avoid variability between assays.

In two children, the HIV-1 RNA values measured after treatment began were below the detection limit of the standard assay. Plasma samples from these children were subsequently tested with $450 \mu \mathrm{l}$ of plasma and a modified assay that had a detection limit of 20 copies of HIV-1 RNA per milliliter. ${ }^{11}$

\section{HIV-1-Specific Immune Responses}

Plasma HIV-1 IgG antibodies were measured with a commercial immunoassay (Cambridge Biotech). The specificity of plasma IgG antibodies for the HIV-l gene product was assessed by a Western blot assay (Cambridge Biotech). A dot blot assay was used to detect plasma IgA antibodies. ${ }^{12}$ Assays to detect HIV-1-specific cytotoxic T lymphocytes were performed after virus-specific stimulation of PBMCs. ${ }^{13}$

\section{Measurement of Antibodies to Childhood Vaccines}

Routine childhood immunizations were administered according to the recommended schedule. IgG antibodies to Haemophilus influenzae and hepatitis B surface antigen were measured by an enzyme-linked immunosorbent assay (ELISA).

\section{RESULTS}

\section{Study Patients}

Eight maternally infected children 2 to 16 months of age (three female and five male) were enrolled in this study; six were 4 months old or less at enrollment (Table 1). All the patients were asymptomatic or only mildly symptomatic ${ }^{15}$ at study entry. Three children (Patients 5, 6, and 8) had never received antiretroviral therapy. The remaining five had received zidovudine therapy.

The regimen of antiretroviral drugs used was well tolerated by all the study patients. No clinically significant adverse events related to the study drugs were reported.

\section{Plasma Nevirapine Concentrations}

The patients' median trough plasma concentrations of nevirapine during the treatment period ranged from 2.7 to $8.6 \mu \mathrm{g}$ per milliliter. There was no apparent association between the trough concentration of nevirapine in plasma and the reduction in plasma HIV-I RNA (data not shown).

\section{Effect of Treatment on the HIV-1 Load} in Peripheral Blood

The patients' plasma HIV-1 RNA levels before therapy ranged from approximately 41,000 to approximately 1.5 million copies per milliliter (Fig. 1). All the patients had rapid reductions in plasma HIV-I RNA;

Table 1. Base-Line Clinical and Laboratory Characteristics of the Study Patients.

\begin{tabular}{|c|c|c|c|c|c|c|}
\hline \multirow{2}{*}{$\begin{array}{l}\text { Patient } \\
\text { No.* }\end{array}$} & \multirow{2}{*}{$\begin{array}{l}\text { AGE AT } \\
\text { ENTRY } \\
\text { (MO) }\end{array}$} & \multirow{2}{*}{$\begin{array}{l}\text { TIMING OF } \\
\text { INFECTIONt }\end{array}$} & \multirow[b]{2}{*}{$\begin{array}{l}\text { Clinical } \\
\text { Stage‡ }\end{array}$} & \multirow{2}{*}{$\begin{array}{c}\text { PRIOR } \\
\text { ANTIRETROVIRAL } \\
\text { THERAPY }\end{array}$} & \multirow[b]{2}{*}{$\begin{array}{l}\text { CD4 } \\
(\%) \S\end{array}$} & \multirow[b]{2}{*}{$\begin{array}{l}\text { HIV-1 RNA } \\
\text { (COPIES/ml) }\end{array}$} \\
\hline & & & & & & \\
\hline 1 & 2 & Unknown & $\mathrm{Al}$ & $\begin{array}{l}\text { Zidovudine for } \\
6 \mathrm{wk}\end{array}$ & 38 & $1,546,242$ \\
\hline 2 & $2^{1 / 2}$ & Late & $\mathrm{Al}$ & $\begin{array}{l}\text { Zidovudine for } \\
5 \mathrm{wk}\end{array}$ & 58 & 295,022 \\
\hline 3 & $2^{1 / 2}$ & Late & $\mathrm{Al}$ & $\begin{array}{l}\text { Zidovudine for } \\
5 \mathrm{wk}\end{array}$ & 44 & 331,036 \\
\hline 4 & $2^{1 / 2}$ & Early & $\mathrm{Al}$ & $\begin{array}{l}\text { Zidovudine for } \\
10 \mathrm{wk}\end{array}$ & 56 & 244,374 \\
\hline 5 & 3 & Unknown & $\mathrm{Al}$ & None & 31 & 466,590 \\
\hline 6 & 4 & Unknown & $\mathrm{Al}$ & None & 32 & 41,516 \\
\hline 7 & 12 & Unknown & $\mathrm{Al}$ & $\begin{array}{l}\text { Zidovudine for } \\
16 \mathrm{wk}\end{array}$ & 28 & 572,424 \\
\hline 8 & 16 & Unknown & $\mathrm{A} 2$ & None & 18 & 195,994 \\
\hline
\end{tabular}

*Patients 2 and 3 were fraternal twins.

$\uparrow$ The definitions of the timing of infection were those used by Bryson et al. ${ }^{14}$

$\ddagger$ Clinical stages were those in the definitions of the Centers for Disease Control and Prevention. ${ }^{15} \mathrm{~A}$ denotes asymptomatic, 1 normal CD4 counts for age, and 2 mildly reduced CD4 counts for age.

\$Data are for CD4 cells as a proportion of all lymphocytes. 


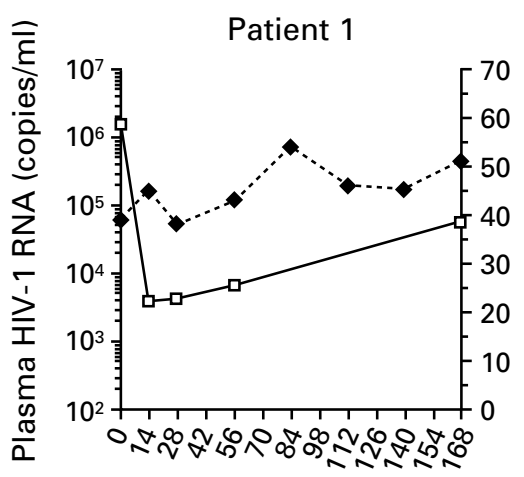

Day

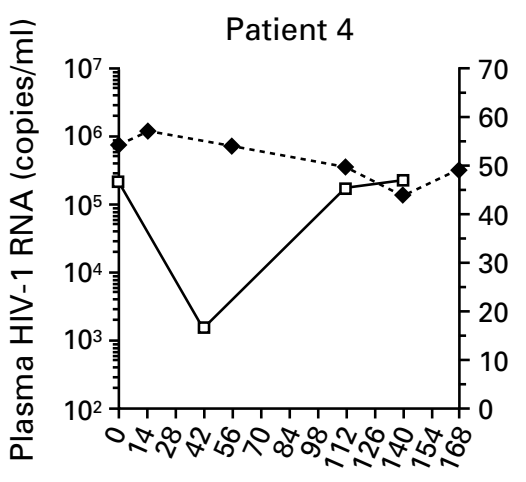

Day
Patient 2

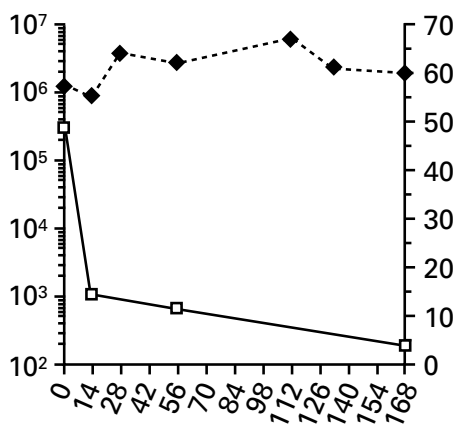

Day

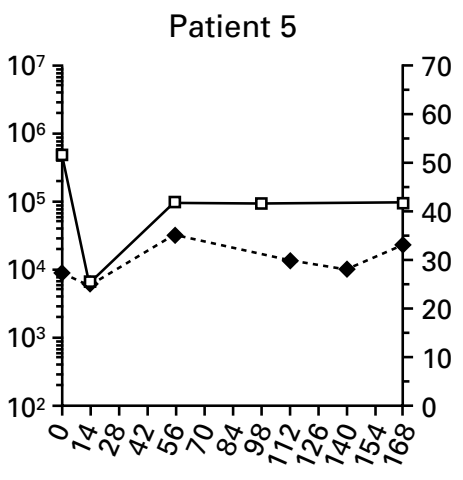

Day

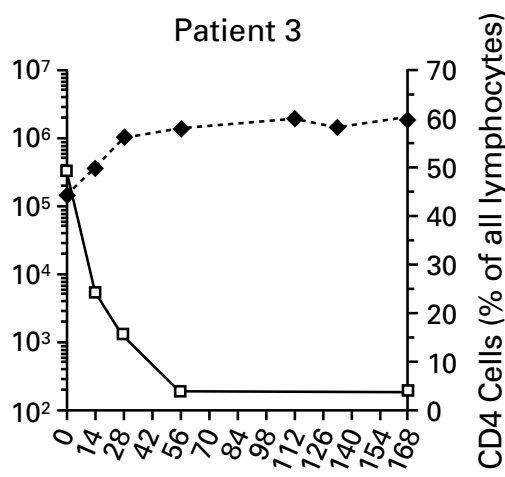

Day

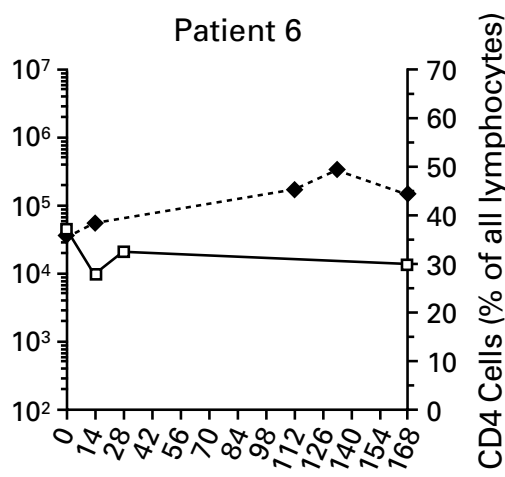

Day
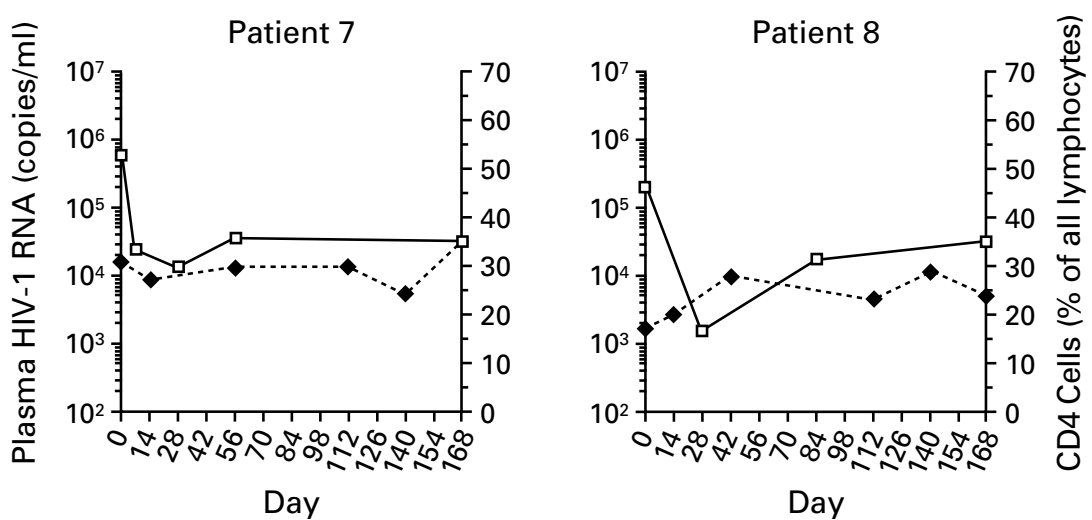

Figure 1. Effect of Combination Therapy with Zidovudine, Didanosine, and Nevirapine on Plasma Levels of HIV-1 RNA ( ——) and on CD4 T Lymphocytes (--- ---) in Peripheral Blood as a Percentage of All Lymphocytes. 


\begin{tabular}{|c|c|c|c|c|}
\hline \multicolumn{5}{|c|}{$\begin{array}{c}\text { TABLE 2. CHA } \\
\text { PlaSMA }\end{array}$} \\
\hline \multirow[t]{2}{*}{$\begin{array}{l}\text { Patient } \\
\text { No. }\end{array}$} & $\begin{array}{l}\text { AGE AT } \\
\text { ENTRY } \\
\text { (MO) }\end{array}$ & \multicolumn{3}{|c|}{ Plasma HIV-1 Titer } \\
\hline & & $\begin{array}{l}\text { BASE } \\
\text { LINE }\end{array}$ & $\begin{array}{c}\mathrm{DAY} \\
28\end{array}$ & $\begin{array}{l}\text { DAY } \\
168\end{array}$ \\
\hline & & \multicolumn{3}{|c|}{ tissue-culture infectious doses $/ \mathrm{m}$} \\
\hline 1 & 2 & 7812 & 0 & 62 \\
\hline 2 & $2^{1 / 2}$ & 312 & 0 & 0 \\
\hline 3 & $21 / 2$ & 62 & 0 & 0 \\
\hline 4 & $2^{1 / 2}$ & 62 & 0 & Not done \\
\hline 5 & 3 & 312 & 0 & 0 \\
\hline 6 & 4 & 0 & 0 & 0 \\
\hline 7 & 12 & 0 & 0 & 0 \\
\hline 8 & 16 & 0 & 0 & 0 \\
\hline
\end{tabular}

Table 3. Changes in HiV-1 Titers in PBMCS OVER Time.

\begin{tabular}{|c|c|c|c|c|}
\hline \multirow[t]{3}{*}{$\begin{array}{l}\text { Patient } \\
\text { No. }\end{array}$} & \multirow[t]{3}{*}{$\begin{array}{l}\text { AGE AT } \\
\text { ENTRY } \\
\text { (MO) }\end{array}$} & \multicolumn{3}{|c|}{ PBMC HIV-1 TITER } \\
\hline & & BASE & DAY & DAY \\
\hline & & LINE & 28 & 168 \\
\hline & & \multicolumn{3}{|c|}{$\begin{array}{l}\text { infectious units/ } \\
\text { million cells }\end{array}$} \\
\hline 1 & 2 & 206 & 16 & 2 \\
\hline 2 & $2^{1 / 2}$ & 82 & 8 & 0 \\
\hline 3 & $2^{1 / 2}$ & 16 & 1 & 0 \\
\hline 4 & $2^{1 / 2}$ & 28 & 9 & 0 \\
\hline 5 & 3 & 206 & 16 & 16 \\
\hline 6 & 4 & 43 & 82 & 0.5 \\
\hline 7 & 12 & 143 & 3 & 0.5 \\
\hline 8 & 16 & 8 & 0 & 3 \\
\hline
\end{tabular}

minimal reductions of 96 percent (a decrease of 1.5 in the $\log$ of the number of copies per milliliter) were observed in seven of the eight infants within two to four weeks of the start of therapy. Plasma HIV-I RNA levels remained below the base-line levels (falling to 4 to 30 percent of base line) through the entire six months of therapy in seven of the eight infants.

Plasma HIV-l RNA levels remained below the base-line levels throughout the six months of therapy in five of the six infants whose treatment began at four months of age or less. Three of these six infants had lasting reductions of at least 96 percent $(1.5 \mathrm{log})$ in their plasma RNA levels over the six months of the study, including a pair of fraternal twins (Patients 2 and 3 ) in whom these levels fell below 400 copies per milliliter by days 168 and 56 , respectively.

The base-line plasma HIV-1 cultures were positive in five of the eight infants at titers ranging from 62 to 7812 tissue-culture infectious doses per milliliter (Table 2). All five of these infants were three months old or less, and only one (Patient 4) was receiving zidovudine when the culture was obtained. Infectious HIV-1 was undetectable in plasma in all the infants by day 28 of therapy and remained undetectable through day 168 in six. One infant (Patient 1) had a positive plasma culture at day 168 and had negative cultures on subsequent follow-up. Plasma cultures from Patient 4 were negative on days 28 and 84; not enough blood was obtained from this patient for plasma cultures to be performed at the end of the study.

HIV-l was isolated from PBMCs from all infants at least twice before therapy began; HIV-l titers in the PBMC cultures before therapy ranged from 8 to 206 infectious units per million cells (Table 3). Reductions in these titers were noted in all the infants but one by day 28 , and all the infants had reduced titers on day 168. PBMC cultures became negative in Patients 2, 3, and 4.

Throughout the study period, HIV-1 provirus was detected by PCR in PBMCs from all the infants, including Patients 2 and 3.

\section{Effects of Treatment on Lymphocytes}

At entry into the study, the percentage of CD4 $\mathrm{T}$ lymphocytes in the peripheral blood was normal for the patient's age in all but one infant (Patient 8 ). The percentage of CD4 $\mathrm{T}$ lymphocytes in the peripheral blood remained stable or increased slightly in all the patients over the course of the study (Fig. 1).

Hypergammaglobulinemia has been frequently described in infants with HIV-l infection and is thought to be due to the activation of $B$ cells by the virus. When they were tested at about the age of one year, three of five infants who began the three-drug regimen before the age of four months had hypergammaglobulinemia (data not shown). In Patients 2 and 3 , the total plasma $\operatorname{IgG}$ levels measured at 13 and 16 months were within the normal limits for the patient's age.

Numbers of CD8 T lymphocytes are expanded early in infants infected by their mothers, largely because of an expansion in the CD8+CD57+ and CD $8+$ DR + populations. ${ }^{16}$ In this study, expanded populations of CD8+CD57+ and CD8+DR+ $\mathrm{T}$ lymphocytes were found in the peripheral blood of infants who had persistently detectable plasma HIV-1 RNA during treatment (data not shown). These lymphocyte populations were not expanded in Patients 2 and 3. 
Immune Responses to HIV-1 and Childhood Immunizations

Diminished antibody responses to routine childhood immunizations have been described in children with HIV-l infection. ${ }^{17}$ The plasma HIV-1 IgG titers measured by ELISA in Patients 2 and 3 decreased with time and became negative (Fig. 2); the kinetics of the HIV-l-antibody clearance was identical to that observed in uninfected infants born to HIV-1-seropositive mothers. Concomitantly, the loss of plasma IgG antibodies to HIV-1 gene products was noted on the Western blot assay (data not shown). HIV-1-specific IgA antibodies were not found in the plasma of either Patient 2 or Patient 3 at 6 and 12 months of age. In contrast, infants who remained positive for plasma HIV-l RNA produced HIV-l-specific IgG antibodies actively. Altogether, the data suggest that the $\operatorname{IgG}$ antibodies detected early in Patients 2 and 3 were passively acquired maternal antibodies that were cleared with time. The failure to produce HIV-1-specific antibodies is consistent with the marked suppression of HIV-1 replication in these two infants.

Antibody responses to $H$. influenzae and hepatitis $B$ virus antigens given at immunization were detected in the peripheral blood of Patients 2 and 3 (data not shown). Variable antibody responses to vaccine antigens were noted in all the other infants.

There was sufficient in vitro proliferation of PBMCs to permit testing for HIV-1-specific cytotoxic T lymphocytes only in samples obtained at $3^{1 / 2}$ months of age from Patient 2 and only in samples obtained at $31 / 2$ and 10 months of age from Patient 3, despite good in vitro proliferation of PBMCs at the same times in response to monoclonal antibody to CD3. No responses of HIV-l-specific cytotoxic T lymphocytes were detected in PBMCs from Patients 2 and 3 .

\section{Follow-up of the Two Infants with Undetectable Plasma HIV-1 RNA}

Longer follow-up of Patients 2 and 3 was undertaken. Since HIV-1 RNA was repeatedly undetectable in their plasma by the routine assay, plasma samples from these infants were also studied by an ultrasensitive assay with a detection limit of 20 copies per milliliter. ${ }^{11}$ In Patient 2, plasma HIV-1 RNA levels remained below 20 copies per milliliter through month 15 of therapy. At 16 months, plasma HIV-1 RNA was detected on two occasions 2 weeks apart (1117 and 1546 copies per milliliter). A review of the records for Patient 2 showed that the child had received an influenza immunization 12 days before HIV-1 RNA was first detected. Therapy with zidovudine, didanosine, and nevirapine was discontinued, and a regimen consisting of zidovudine, lamivudine (Epivir, Glaxo Wellcome), and ritonavir (Norvir, Abbott Laboratories) was instituted. Three

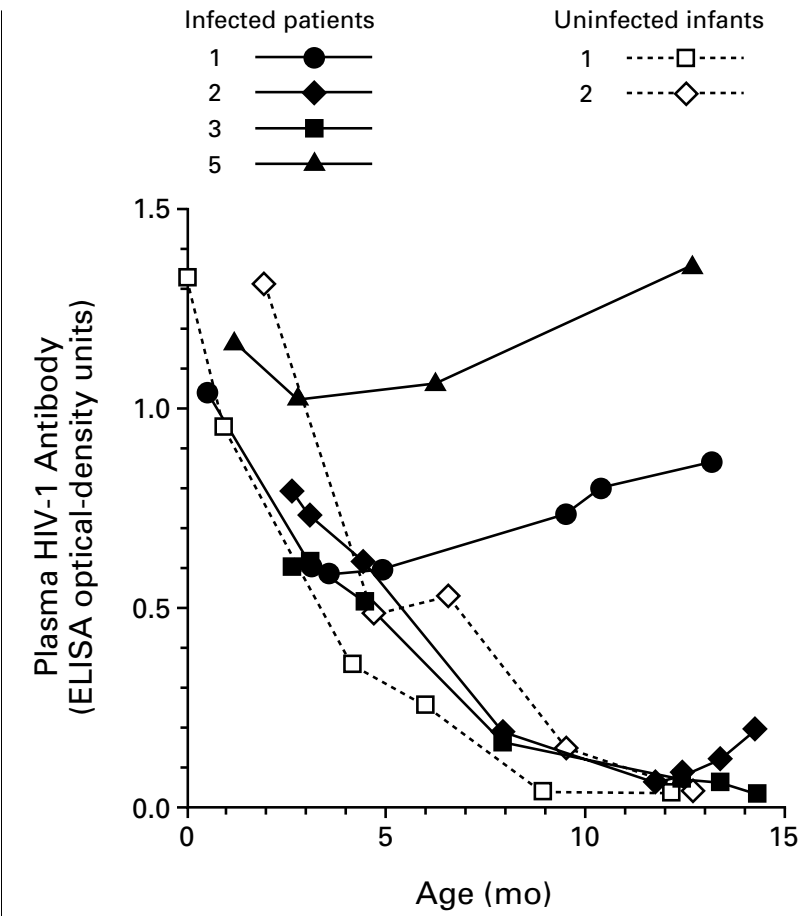

Figure 2. Changes in Plasma Titers of HIV-1 Antibody over Time in Four HIV-1-Infected Patients Given Three-Drug Combination Therapy and Two Uninfected Infants Born to HIV-1-Infected Mothers.

weeks after the antiretroviral therapy was switched, the plasma HIV-1 RNA level was again below 400 copies per milliliter, and it remained at that level throughout an additional month of follow-up (month 18). Interestingly, HIV-l-specific IgG antibodies were detected by ELISA and the Western blot assay in this child's plasma concurrently with the detection of HIV-I RNA. Despite the transient detection of plasma HIV-1 RNA, HIV-l has not been recovered from plasma or PBMCs. Peripheral-blood CD4 and CD8 T-cell counts have remained normal for the patient's age.

Patient 3 has continued to be treated with zidovudine, didanosine, and nevirapine for 18 months. During this period, she has received all routine childhood immunizations. Her plasma HIV-l RNA level has remained below 20 copies per milliliter. No HIV-l-specific IgG antibodies have been detectable in plasma by ELISA. The HIV-1 genome has been persistently detected at a level of 100 to 178 copies per million CD4 T lymphocytes. The proportions of CD4 and CD8 T lymphocytes have remained normal for the patient's age.

\section{DISCUSSION}

We evaluated the safety and antiretroviral activity of a three-drug combination therapy in HIV-1infected infants and children. Since six of the eight 
infants began their therapy before the age of five months, we also evaluated the efficacy of the combination therapy when it was begun early in the course of maternally acquired HIV-1 infection. The treatment was well tolerated, with no clinically significant adverse events. Of the eight infants, seven had reductions of at least $0.5 \mathrm{log}$ in their plasma HIV-1 RNA levels throughout the six months of therapy. The antiretroviral activity of the combination therapy in maternally infected infants was therefore similar to that reported in adults with no previous antiretroviral therapy. ${ }^{18}$

In a study of nevirapine monotherapy, ${ }^{7}$ the loss of antiretroviral activity over time was associated with the isolation of viruses with decreased in vitro sensitivity to nevirapine. In our study, all the viruses isolated from the study patients before therapy were sensitive to nevirapine (data not shown). Viruses with decreased sensitivity to nevirapine were isolated during the treatment period from all five infants (Patients 1, 4, 5, 6, and 8) who had partial rebounds in their plasma HIV-1 RNA levels. Viruses isolated from Patients 2, 3, and 7 remained susceptible to nevirapine. The emergence of resistance may explain the partial loss of antiretroviral activity observed in some infants.

Over the six months of the study, there was clearance of detectable plasma HIV-1 RNA in a pair of fraternal twins (Patients 2 and 3 ) who had the intrapartum (or "late") pattern of infection. The twins began combination therapy at the age of $2 \frac{1}{2}$ months. Their outcomes after three-drug therapy have differed during follow-up. Although the baseline plasma HIV-1 RNA levels in Patients 2 and 3 were similar, HIV-1 RNA was cleared more rapidly from the plasma of Patient 3 and remained undetectable through month 18 of therapy. Patient 2 was slower to have clearance of HIV-1 RNA, and RNA was detected again in this infant's plasma after month 16 of therapy.

Interestingly, infectious plasma and PBMC titers before therapy were higher in Patient 2 than in Patient 3 , suggesting that Patient 2 may have had a higher initial inoculum of infectious virus. Although these twins were probably infected with a single viral strain or with closely related strains, infection with different strains could explain the divergent outcomes. However, host factors, such as the size of the pool of activated CD4 $\mathrm{T}$ lymphocytes and differences in immune responses, may have influenced the outcomes. Extinguishing HIV-1 replication took longer in both infants than the estimated two to three weeks previously proposed. ${ }^{6}$ This may be due to differences in the potency or mechanisms of action of the antiretroviral drugs used. Alternatively, the slower rate of HIV-1 RNA clearance may be due to the larger pools of activated CD4 $\mathrm{T}$ lymphocytes in young infants.
It has been predicted that during primary infection in adults, using therapeutic regimens that completely inhibit viral replication may lead to the complete eradication of HIV-1 within two to three years. Whether continued control of HIV-1 replication and eventual viral eradication will occur in Patients 2 and 3 with the current combination of drugs depends on the longevity of the infected cell populations, the proportion of latently infected cells that is capable of producing infectious viruses, and the ultimate efficiency of the combination therapy in preventing new infections of cells. It may also depend on the ability of antiretroviral agents to penetrate potential "sanctuary" sites, such as the central nervous system, and control viral replication there. Both zidovudine and nevirapine penetrate the central nervous system well.

We studied HIV-1-specific and general immune responses in the infants who began three-drug therapy before the age of four months. Active production of HIV-1-specific antibodies was documented in all the children with ongoing replication of HIV-1. In contrast, the active production of HIV-1 IgA and IgG antibodies was not observed in Patients 2 and 3, even though high titers of infectious virus were isolated from their plasma and PBMCs for several weeks before therapy. This finding is compatible with one of documented seroreversion in an infant recently reported to have had clearance of maternally acquired HIV-1 infection ${ }^{19}$ and with the transient, low-level antibody production in neonatal macaques with limited replication of simian immunodeficiency virus in early infection. ${ }^{20}$ The presence of high titers of maternal HIV-1 antibody when viral replication began may have dampened primary humoral immune responses. Alternatively, the large number of CD4 T cells initially infected may have impaired helper function and may account for the lack of detectable HIV-1-specific humoral and cytotoxic-T-lymphocyte responses. The normal immunoglobulin levels for the patient's age, the responses to vaccine antigens, and the subsequent seroconversion in Patient 2 suggest that infants who begin combination antiretroviral therapy early are capable of normal humoral immune responses.

Although most of the study patients were treated earlier and more aggressively than is currently the standard of care, our data suggest that instituting potent antiretroviral therapies even earlier is desirable. The high base-line plasma HIV-1 RNA levels and the rapid, profound reductions we observed in these levels are consistent with extremely rapid rates of viral turnover. Coffin ${ }^{21}$ has estimated that, on average, a mutation occurs several times daily at every position in the HIV-1 genome. Although minimal genotypic heterogeneity has been described in even highly variable regions (such as the V3 region of the envelope 
protein 22,23 ) of isolates obtained in early maternally acquired infection, our data suggest that by the age of two to three months diversification may have occurred to such a degree that mutations conferring resistance to antiretroviral drugs were present before therapy and were selected during therapy.

Altogether, these considerations suggest that therapy with potent combinations of antiretroviral drugs should be started as early as possible in infants with maternally acquired infection (probably within the first two to four weeks), to minimize the likelihood that antiretroviral resistance will emerge and to maximize the opportunity for long-term control of HIV-1 replication. Recent advances in the ability to diagnose maternally acquired HIV-l infection within weeks of infection ${ }^{24}$ should permit this strategy to be evaluated.

Supported in part by the AIDS Clinical Trial Group (AIDS Clinical Trials Group protocol 180) and the National Institute of Allergy and Infectious Diseases, National Institutes of Health (AI32907, AI27550, and AI30629); by the General Clinical Research Center Units, National Center for Research Resources (University of Connecticut and University of California at Los Angeles); and by Boehringer-Ingelheim Pharmaceuticals. Dr. Luzuriaga is an Elizabeth Glaser Scientist of the Pediatric AIDS Foundation.

We are indebted to the study patients and their guardians for their participation; to Heather Macy, Maureen Myers, and Elizabeth Hawkins for their help with protocol development and study management; to Joe Pav for the analysis of plasma nevirapine levels; to Jerry Durbin, Donna Picard, Amy Sharples, Dottie Smith, Lorraine Wells, Maripat Toye, and Dena Jung for clinical assistance; to Kevin Byron, Balaka Roy, Linda Lambrecht, Richard Hudson, Michelle Sicard, Frank Brewster, and Ruth Dickover for the virologic assays; to John Mulder (Roche Molecular Systems, Inc.) for the ultrasensitive RNA assays; to Carmen White and Diane Wara for the HIV-1-specific IgA assays; to Margaret McManus for graphics and data management; and to Melinda Gromack for assistance in the preparation of the manuscript.

\section{REFERENCES}

1. Stoneburner RL, Sato P, Burton A, Mertens T. The global HIV pandemic. Acta Paediatr Suppl 1994;400:1-4.

2. The European Collaborative Study. Natural history of vertically acquired human immunodeficiency virus-1 infection. Pediatrics 1994;94: $815-9$.

3. Piatak M Jr, Saag MS, Yang LC, et al. High levels of HIV-l in plasma during all stages of infection determined by competitive PCR. Science 1993;259:1749-54

4. Ho DD, Neumann AU, Perelson AS, Chen W, Leonard JM, Markowitz M. Rapid turnover of plasma virions and CD4 lymphocytes in HIV-l infection. Nature 1995;373:123-6.
5. Wei X, Ghosh SK, Taylor ME, et al. Viral dynamics in human immunodeficiency virus type 1 infection. Nature 1995;373:117-22.

6. Perelson AS, Neumann AU, Markowitz M, Leonard JM, Ho DD.

HIV-1 dynamics in vivo: virion clearance rate, infected cell life-span, and viral generation time. Science 1996;271:1582-6.

7. Luzuriaga K, Bryson Y, McSherry G, et al. Pharmacokinetics, safety, and activity of nevirapine in human immunodeficiency virus type l-infected children. J Infect Dis 1996;174:713-21.

8. AIDS Clinical Trials Group. Virology reference manual. Bethesda, Md. National Institutes of Health, 1993.

9. Greenough TC, Brettler DB, Somasundaran M, Panicali DL, Sullivan JL. HIV-1-specific cytotoxic T lymphocytes (CTL), viral load, and CD4 T cell loss: evidence supporting a predominantly protective role for CTL in vivo. J Infect Dis (in press).

10. Saag MS, Holodniy M, Kuritzkes DR, et al. HIV viral load markers in clinical practice. Nat Med 1996;2:625-9.

11. Christopherson C, Mulder J, Conway B, et al. Evaluation of HIV-1 proviral DNA in patients with undetectable RNA. Presented at the Fourth Conference on Retroviruses and Opportunistic Infections, Washington, D.C., January 22-26, 1997.

12. Martin NL, Levy JA, Legg H, Weintrub PS, Cowan MJ, Wara DW. Detection of infection with human immunodeficiency virus (HIV) type 1 in infants by an anti-HIV immunoglobulin A assay using recombinant proteins. J Pediatr 1991;118:354-8.

13. Lubaki MN, Egan MA, Siliciano RF, Weinhold KJ, Bollinger RC. A novel method for detection and ex vivo expansion of HIV type 1-specific cytolytic T lymphocytes. AIDS Res Hum Retroviruses 1994;10:1427-31. 14. Bryson YJ, Luzuriaga K, Sullivan JL, Wara DW. Proposed definitions for in utero versus intrapartum transmission of HIV-1. N Engl J Med 1992;327:1246-7.

15. 1994 Revised classification system for human immunodeficiency virus infection in children less than 13 years of age. MMWR Morb Mortal Wkly Rep 1994;43(RR-12):1-10.

16. Luzuriaga K, Koup RA, Pikora CA, Brettler DB, Sullivan JL. Deficient human immunodeficiency virus type $\mathrm{l}$-specific cytotoxic $\mathrm{T}$ cell responses in vertically infected children. J Pediatr 1991;1 19:230-6.

17. Peters VB, Sood SK. Immunity to Haemophilus influenzae type b polysaccharide capsule after vaccination with the complete series of oligosaccharide $\mathrm{CRM}_{197}$ conjugate vaccine in infants with human immunodeficiency virus infection. J Pediatr 1996;128:363-5.

18. Myers M, Montaner J, Group IS. A randomized, double-blinded comparative trial of the effects of zidovudine, didanosine, and nevirapine combinations in antiviral naive, AIDS-free, HIV-infected patients with CD4 counts $200-600 / \mathrm{mm}^{3}$. In: Abstracts of the XI International Conference on AIDS, Vancouver, B.C., July 7-12, 1996:22. abstract.

19. Bryson YJ, Pang S, Wei LS, Dickover R, Diagne A, Chen ISY. Clearance of HIV infection in a perinatally infected infant. N Engl J Med 1995 332:833-8

20. Wyand MS, Manson KH, Lackner AA, Desrosiers RC. Resistance of neonatal monkeys to live attenuated vaccine strains of simian immunodeficiency virus. Nat Med 1997;3:32-6.

21. Coffin JM. HIV population dynamics in vivo: implications for genetic variation, pathogenesis, and therapy. Science 1995;267:483-9.

22. Scarlatti G, Leitner T, Halapi E, et al. Comparison of variable region 3 sequences of human immunodeficiency virus type 1 from infected children with the RNA and DNA sequences of the virus populations of their mothers. Proc Natl Acad Sci U S A 1993;90:1721-5.

23. Wolinsky SM, Wike CM, Korber BTM, et al. Selective transmission of human immunodeficiency virus type-1 variants from mothers to infants. Science 1992;255:1134-7.

24. Luzuriaga K, Sullivan JL. DNA polymerase chain reaction for the diagnosis of vertical HIV infection. JAMA 1996;275:1360-1. 